\title{
Hypercholesterolemia in Low Density Lipoprotein Receptor Knockout Mice and its Reversal by Adenovirus-mediated Gene Delivery
}

\author{
Shun Ishibashi, * Michael S. Brown, ${ }^{\star}$ Joseph L. Goldstein, * Robert D. Gerard, ${ }^{\star}$ Robert E. Hammer, ${ }^{*}$ and Joachim Herz * \\ Departments of *Molecular Genetics and ${ }^{\star}$ Biochemistry and ${ }^{\S}$ Howard Hughes Medical Institute, University of Texas Southwestern \\ Medical Center at Dallas, Dallas, Texas 75235
}

\begin{abstract}
We employed homologous recombination in embryonic stem cells to produce mice lacking functional LDL receptor genes. Homozygous male and female mice lacking LDL receptors ( $L D L R^{-1-}$ mice) were viable and fertile. Total plasma cholesterol levels were twofold higher than those of wild-type littermates, owing to a seven- to ninefold increase in intermediate density lipoproteins (IDL) and LDL without a significant change in HDL. Plasma triglyceride levels were normal. The half-lives for intravenously administered ${ }^{125} \mathrm{I}-\mathrm{VLDL}$ and ${ }^{125} \mathrm{I}$ LDL were prolonged by 30 -fold and 2.5 -fold, respectively, but the clearance of ${ }^{125} \mathrm{I}-\mathrm{HDL}$ was normal in the $L D L R^{-/-}$mice. Unlike wild-type mice, $L D L R^{-/-}$mice responded to moderate amounts of dietary cholesterol $(0.2 \%$ cholesterol $/ 10 \%$ coconut oil) with a major increase in the cholesterol content of IDL and LDL particles. The elevated IDL/LDL level of $L D L R^{-1-}$ mice was reduced to normal $4 \mathrm{~d}$ after the intravenous injection of a recombinant replication-defective adenovirus encoding the human LDL receptor driven by the cytomegalovirus promoter. The virus restored expression of LDL receptor protein in the liver and increased the clearance of ${ }^{125} \mathrm{I}-\mathrm{VLDL}$. We conclude that the LDL receptor is responsible in part for the low levels of VLDL, IDL, and LDL in wild-type mice and that adenovirusencoded LDL receptors can acutely reverse the hypercholesterolemic effects of LDL receptor deficiency. (J. Clin. Invest. 1993. 92:883-893.) Key words: homologous recombination • lipoprotein metabolism • very low density lipoprotein • gene therapy • liver receptors
\end{abstract}

\section{Introduction}

The LDL receptor removes cholesterol-rich intermediate density lipoproteins (IDL) ${ }^{1}$ and LDL from plasma and thereby regulates the plasma cholesterol level (1). The lipoproteins that

\section{Received for publication 1 April 1993.}

1. Abbreviations used in this paper: AdCMV-Luc, recombinant adenovirus containing luciferase cDNA; AdCMV-LDLR, recombinant adenovirus containing human LDL receptor CDNA; CMV, cytomegalovirus; ES, embryonic stem cells; FH, familial hypercholesterolemia; FPLC, fast performance liquid chromatography; IDL, intermediate density lipoproteins; LRP, LDL receptor-related protein $/ \alpha_{2}$-macroglobulin receptor; $L D L R^{-1-}$ and $L D L R^{+/-}$, mice homozygous and heterozygous, respectively, for LDL receptor gene disruption; pfu, plaque-forming units; WHHL, Watanabe-heritable hyperlipidemic rabbits.

J. Clin. Invest.

(c) The American Society for Clinical Investigation, Inc.

$0021-9738 / 93 / 08 / 0883 / 11 \$ 2.00$

Volume 92, August 1993, 883-893 bind to the LDL receptor are derived from triglyceride-rich VLDL, which are secreted by the liver. In the circulation some of the triglycerides of VLDL are removed by lipoprotein lipase, and the resultant IDL particle is cleared rapidly into the liver, owing to its content of apolipoprotein $\mathrm{E}$ (apo $\mathrm{E}$ ), a high affinity ligand for the LDL receptor. Some IDL particles escape hepatic uptake and are converted to LDL in a reaction that leads to the loss of apo E. The sole remaining protein, apo B-100, binds to LDL receptors with relatively low affinity, thus causing LDL particles to circulate for relatively prolonged periods (2).

Triglyceride-depleted, cholesterol-rich remnants of intestinal chylomicrons are taken into the liver by the LDL receptor and by a genetically distinct molecule designated the chylomicron remnant receptor $(3,4)$. The latter receptor recognizes apo $E$ when it is present on chylomicron remnant particles together with apo B-48, a truncated version of apo B-100 that is produced in the intestine (3). Circumstantial evidence suggests that the chylomicron remnant receptor is the same as the LDL receptor-related protein $/ \alpha_{2}$-macroglobulin receptor (LRP) (4). The action of this receptor may be facilitated by the preliminary binding of the chylomicron remnants to cell-associated glycosaminoglycans in hepatic sinusoids (5).

Genetic defects in the LDL receptor produce hypercholesterolemia in humans with familial hypercholesterolemia (FH) (6), Watanabe-heritable hyperlipidemic (WHHL) rabbits (7), and rhesus monkeys (8). Humans and rabbits with two defective LDL receptor genes (FH and WHHL homozygotes) have massively elevated levels of IDL and LDL, and they develop fulminant atherosclerosis at an early age. Tracer studies with ${ }^{125}$ I-labeled lipoproteins revealed a retarded clearance of IDL and LDL, and an increased conversion of IDL to LDL in humans (9) and rabbits (10) with LDL receptor deficiency.

Evidence from one human pedigree (11) and from monozygotic/dizygotic twin pair correlations (12) indicates that other genes can influence the degree of hypercholesterolemia in subjects with LDL receptor deficiency. These genes are likely to influence cholesterol levels even in people with normal LDL receptors. Identification of these genes has not been possible in human linkage studies, nor in breeding experiments with WHHL rabbits. Linkage studies would be facilitated by the availability of an inbred mouse strain with LDL receptor deficiency. The consequences of LDL receptor deficiency in mice are difficult to predict because mice, like rats, have a fundamental difference in LDL metabolism when compared with other species that have been studied (13). In mice and rats a substantial fraction of the VLDL secreted from liver contains apo B-48 instead of apo B-100 (14-16). Remnants derived from the apo B-48 containing particles are cleared into the liver and are not converted to LDL (17). Some of this clearance may be mediated by the chylomicron remnant receptor. For this reason, LDL receptor deficiency in mice would not be predicted to raise the plasma LDL level as profoundly as it does in WHHL rabbits. 
Mice deficient in LDL receptors might also aid in the development of gene therapy techniques designed to enhance the expression of hepatic LDL receptors. Using homozygous WHHL rabbits as a model, Chowdhury et al. (18) infected autologous hepatocytes ex vivo with a recombinant retrovirus carrying an expressible cDNA copy of the rabbit LDL receptor under control of the chicken $\beta$-actin promoter. After infusion of these transduced hepatocytes into the spleen, LDL receptor expression was visualized in $2-4 \%$ of liver cells. Although functional studies of ${ }^{125} \mathrm{I}$-LDL turnover were not performed, these workers observed a fall of $\sim 30 \%$ in the level of total plasma cholesterol, which did not occur in animals injected with hepatocytes transduced with a control retrovirus encoding an irrelevant protein. With this technique the expression of LDL receptors persisted for 2-4 mo. Although the $30 \%$ reduction in plasma cholesterol was statistically significant, the level remained quite elevated (above $500 \mathrm{mg} / \mathrm{dl}$ ) when compared with normal rabbits, $(<100 \mathrm{mg} / \mathrm{dl})$, presumably owing to the expression of LDL receptors in only a small percentage of hepatocytes. Similar results were obtained in transient experiments following the intravenous injection of a plasmid containing the LDL receptor CDNA complexed to an asialo-orosomucoid/poly-L-lysine conjugate (19).

In mice, gene manipulation has produced significant effects on LDL receptor expression. Several years ago Hofmann et al. (20) and Yokode et al. (21) produced transgenic mice that overexpressed hepatic LDL receptors encoded by the human LDL receptor gene driven by the metallothionein or transferrin promoter. They showed that these receptors enhanced the clearance of radiolabeled LDL from plasma of normal mice. Yokode et al. (22) then demonstrated that these mice were resistant to the cholesterol-elevating effects of a high cholesterol diet.

Recently, Herz and Gerard (23) developed a recombinant replication-defective adenovirus vector containing an expressible cDNA copy of the human LDL receptor driven by the cytomegalovirus (CMV) promoter. $4 \mathrm{~d}$ after its intravenous injection, this virus elicited the expression of high levels of human LDL receptors in more than $90 \%$ of mouse hepatocytes, and this enhanced markedly the uptake of ${ }^{125}$ I-LDL by the liver. The use of adenovirus vectors was based on the observations of Stratford-Perricaudet et al. (24), who injected recombinant adenoviruses encoding ornithine transcarbamylase into neonatal mice homozygous for a defect in this gene. The recombinant adenovirus produced a level of enzyme activity in liver sufficient to eliminate the pathologic manifestations of the disease, and expression apparently persisted for $1 \mathrm{yr}$.

The current studies were conducted in order to learn the consequences of LDL receptor deficiency in mice and to learn whether adenovirus vectors will acutely reverse these consequences. For these purposes, we have used the techniques of homologous recombination in cultured embryonic stem (ES) cells (25-27) to produce mice that lack functional LDL receptors. We show that these mice develop a marked elevation in plasma IDL and LDL levels when compared with control mice and that this elevation can be eliminated acutely by the intravenous administration of a recombinant adenovirus encoding the human LDL receptor.

\section{Methods}

General methods. Unless otherwise indicated, DNA -manipulations were performed by standard techniques (28). Immunoblot (29) and ligand blot analyses (30) were performed as described in the indicated references. Cholesterol and triglycerides were determined enzymatically with assay kits obtained from Boehringer Mannheim (Biochemicals, Indianapolis, IN) and Sigma Chemical Co. (St. Louis, MO), respectively. The normal mouse diet (Teklad 4\% Mouse/Rat Diet 7001 from Harlan Teklad Premier Laboratory Diets, Madison, WI) contained 4\% (wt/wt) animal fat with $<0.04 \%$ (wt/wt) cholesterol. Mouse VLDL $(d<1.006 \mathrm{~g} / \mathrm{ml}), \operatorname{LDL}(d 1.025-1.50 \mathrm{~g} / \mathrm{ml})$, and HDL $(d 1.063-1.215 \mathrm{~g} / \mathrm{ml})$ were isolated by sequential ultracentrifugation (31) from pooled plasma obtained from $L D L R^{-1-}$ mice that had been fasted overnight. Rabbit VLDL $(d<1.006 \mathrm{~g} / \mathrm{ml})$ was isolated by the same procedure from plasma obtained from fasted WHHL rabbits. Lipoproteins were radiolabeled with ${ }^{125}$ I by the iodine monochloride method (31). A $0.2 \%$ cholesterol $/ 10 \%$ coconut oil diet was prepared by supplementing the normal mouse diet with $0.2 \%$ (wt/wt) cholesterol dissolved in a final concentration of $10 \%$ ( $\mathrm{vol} / \mathrm{wt}$ ) coconut oil.

Cloning of mouse $L D L$ receptor $c D N A$. Mouse $L D L$ receptor $c D N A$ was amplified by PCR from mouse liver first strand cDNA using poly $(\mathrm{A})^{+}$RNA and the following primers:

Primer A, 5'-ATTCTAGAGGGTGAACTGGTGTGAG-3' (exon 14);

Primer B, 5'-ATAATTCACTGACCATCTGTCTCGAGGGGTAG3' (exon 18);

Primer C, 5'-AAATG(T/C)ATC(T/G)(T/C)C(T/A)GCAAGTGGGTCTG(C/T)GA(T/C)GGCAG-3' (exon 2);

Primer D 5'-CTGCTCCTCATTCCCTCTGCCAGCCA-3' (exon 16).

Amplification with primers A and B yielded a cDNA fragment corresponding to exons 14-18. cDNA spanning exons 2-16 was amplified with primers $C$ and $D$. Primers A, B, and C were designed and based on the conservation of the LDL receptor coding sequence between human, rabbit, hamster, rat, and cow $(32,33)$. Primer $\mathrm{D}$ was designed and based on the mouse exon 16 cDNA sequence contained in the amplification product obtained with primers $A$ and $B$. Amplification products were blunt-end cloned into pGEM3Zf(+) (Promega Corp., Madison, WI) and sequenced.

Construction of gene replacement vector. Southern blot analysis of mouse C57B1/6 genomic DNA with an exon 2-16 cDNA probe revealed a 16-kb BamHI fragment. This fragment was enriched by sucrose density ultracentrifugation and cloned into the $\lambda$ Dash II vector (Stratagene Corp., La Jolla, CA), and recombinant phages containing the fragment were isolated by plaque screening. After subcloning into pGEM3Zf (+), the Pol2sneobpA expression cassette (34) was inserted into a unique SalI site in exon 4 (Fig. 1). This neo expression cassette was flanked by $12 \mathrm{~kb}$ of LDL receptor genomic sequences including exons 1 to 4 . The short arm of the targeting vector contained a $1.2-\mathrm{kb}$ SalI-SacI fragment with sequences of exon 4 and intron 4 . The Sall sites were destroyed during the cloning. Two copies of the herpes simplex thymidine kinase gene (35) were inserted in tandem at the $3^{\prime}$ end of the short arm of the targeting vector (Fig. 1).

ES cell culture. Mouse ES cells (AB-1, kindly provided by A. Bradley, Baylor College of Medicine, Houston) were cultured on leukemia inhibitory factor-producing STO feeder cells as described (36). Approximately $2 \times 10^{7}$ cells were electroporated with linearized targeting vector $(25 \mu \mathrm{g} / \mathrm{ml}, 275 \mathrm{~V}, 330 \mu \mathrm{F})$ in an electroporator (GIBCO Bethesda Research Laboratories) and seeded onto irradiated feeder layers $(10,000 \mathrm{rad})$. After selection with $190 \mu \mathrm{g} / \mathrm{ml} \mathrm{G} 418$ and $0.25 \mu \mathrm{M} 1-[2$ deoxy, 2-fluoro- $\beta$-D-arabinofuranosyl]-5 iodouracil (FIAU; BristolMyers Co., New York, NY) recombinant clones were identified by PCR as described (34) using Primers E and F (Primer E, located in 3'-untranslated region of neo cassette, 5'-GATTGGGAAGACAATAGCAGGCATGC-3'; Primer F, located in intron 4, 5'-GGCAAGATGGCTCAGCAAGCAAAGGC-3'). Homologous recombination was verified by Southern blot analysis after $B a m H I$ digestion and probing with a genomic DNA fragment located 3 ' of the targeting construct (Fig. 1). Nine independent stem cell clones containing a disrupted LDL receptor allele were injected into C57B1/6 blastocysts (27), yielding a total of 17 chimeric males whose coat color (agouti) indi- 
cated a contribution of stem cells ranging from 30 to $100 \%$. Of the 17 chimeric males, 15 were fertile, and 13 gave offspring that carried the disrupted LDL receptor allele. Five of these males exclusively transmitted the stem cell-derived genome through the germline. All experiments were performed with the F2 or F3 generation descendants, which were hybrids between the C57B1 /6J and 129Sv strains.

Plasma lipoprotein analysis. Blood was sampled from the retro-orbital plexus into tubes containing EDTA (Microvette CB 1000 capillary tubes; Sarstedt, Inc., Newton, NC). Pooled mouse plasma ( $0.6 \mathrm{ml}$ from 3 to 5 mice) was ultracentrifuged at $d=1.215 \mathrm{~g} / \mathrm{ml}$, and the resulting lipoprotein fraction $(d<1.215 \mathrm{~g} / \mathrm{ml})$ was subjected to fast performance liquid chromatography (FPLC) gel filtration on a Superose 6 (Sigma Chemical Co.) column as previously described (22). For apoprotein analysis, peak fractions were pooled, precipitated with trichloroacetic acid, washed with acetone, and subjected to electrophoresis on 3-15\% SDS polyacrylamide gels as described (22). Gels were calibrated with Rainbow high molecular weight markers (Amersham Corp., Arlington Heights, IL) and stained with Coomassie blue.

Preparation of recombinant adenoviruses. Recombinant replication-deficient adenoviruses containing the firefly luciferase cDNA (AdCMV-Luc) and the human LDL receptor cDNA (AdCMVLDLR) driven by the cytomegalovirus promoter/enhancer were prepared as previously described (23). Briefly, virus particles for injection into animals were grown on human embryonic kidney 293 cells and purified by cesium chloride density gradient centrifugation. Particles were further purified by gel filtration on a Sepharose CL-4B (Pharmacia LKB Biotechnology, Piscataway, $\mathrm{NJ}$ ) column equilibrated with 10 $\mathrm{mM}$ Tris- $\mathrm{HCl}, 137 \mathrm{mM} \mathrm{NaCl}, 5 \mathrm{mM} \mathrm{KCl}, 1 \mathrm{mM} \mathrm{MgCl}_{2}$ at $\mathrm{pH}$ 7.4. BSA was added at a final concentration of $1 \mathrm{mg} / \mathrm{ml}$, after which each virus preparation was stored in multiple aliquots at $-70^{\circ} \mathrm{C}$. Viruses were titered on 293 cells; the titer ranged between $10^{10}$ and $10^{11}$ plaqueforming units (pfu) per ml.

For administration to mice, each recombinant adenovirus was injected as a single dose $\left(2 \times 10^{9} \mathrm{pfu}\right.$ in $\left.200 \mu \mathrm{l}\right)$ into the external jugular vein of a nonfasted animal that had been anesthetized with sodium pentobarbital as previously described (23)

Immunohistochemistry. Mice were killed $4 \mathrm{~d}$ after injection of recombinant virus, the liver was removed, and a sector extending from the surface of the liver to the portal area was immediately frozen (without fixation) in OCT Compound 4583 (Miles Laboratories, Inc., Elkhart, IN) at $-196^{\circ} \mathrm{C}$ and stored at $-70^{\circ} \mathrm{C}$ until cutting. For immunohistochemistry, sections of $6 \mu \mathrm{m}$ were cut on a Leitz Cryostat (E. Leitz, Inc., Rockleigh, $\mathrm{NJ}$ ) at $-20^{\circ} \mathrm{C}$ and mounted onto polylysine-coated slides. Before immunostaining, tissue sections were fixed in $100 \%$ ( vol/ vol) methanol at $-20^{\circ} \mathrm{C}$ for $30 \mathrm{~s}$ followed by two washes in PBS. All incubations were performed at $20^{\circ} \mathrm{C}$. Samples were blocked by incubation for 20 min with $50 \mathrm{mM}$ Tris- $\mathrm{HCl}, 80 \mathrm{mM} \mathrm{NaCl}, 2 \mathrm{mM} \mathrm{CaCl}_{2}$ at pH 8 containing $10 \%$ ( vol/vol) fetal calf serum. Sections were then incubated for $1 \mathrm{~h}$ with $20 \mu \mathrm{g} / \mathrm{ml}$ of polyclonal rabbit IgG directed against the bovine LDL receptor (37) followed by three 5-min washes with PBS. Bound primary antibody was detected by incubation for 45 min with the indicated concentrations of FITC-labeled goat anti-rabbit IgG (GIBCO Bethesda Research Laboratories, Gaithersburg, MD). Slides were washed again three times in PBS, rinsed once briefly in water, and mounted under a coverslip with DABCO $(90 \% \mathrm{vol} / \mathrm{vol}$ glycerol, $50 \mathrm{mM}$ Tris- $\mathrm{HCl}$ at $\mathrm{pH} \mathrm{9,25 \%} \mathrm{(wt/vol)} \mathrm{1,4-diazadicyclo-}$ [2.2.2]-octane).

\section{Results}

To disrupt the LDL receptor gene in murine ES cells, we constructed a gene targeting vector of the replacement type (35) as described in Methods. The targeting vector and the expected genomic structure of the disrupted locus are shown in Fig. 1. The neo cassette was inserted into exon 4 of the LDL receptor gene. The disrupted locus is predicted to encode a nonfunctional protein that is truncated within the ligand binding do-

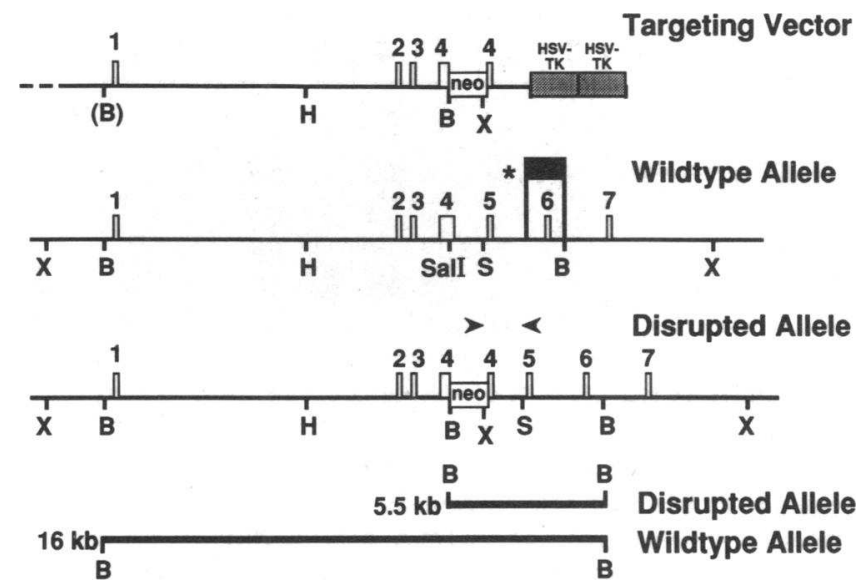

Figure 1. Strategy for targeted disruption of the LDL receptor locus in the mouse genome. A targeting vector of the replacement type was constructed as described in Methods. The neo gene is driven by the murine RNA polymerase II promoter and followed by the 3'-untranslated region of the bovine growth hormone gene containing the polyadenylation signal (34). The transcriptional direction of the neo gene is parallel to that of the LDL receptor. Two copies of the herpes simplex virus thymidine kinase gene (HSV-TK) (reference 35) flank the 3 ' homology segment. In the event of homologous recombination, the disrupted allele will have acquired additional sites for the restriction endonucleases $\mathrm{BamHI}(B)$ and $\mathrm{XbaI}(X)$. The expected BamHI digestion pattern resulting from a targeting event is shown at the bottom. The DNA probe used for Southern blotting (denoted by the asterisk and the heavy bracket) is a 1.7-kb $\mathrm{Bgl} \mathrm{II}-\mathrm{BamHI}$ genomic fragment containing exon 6 and flanking intron sequences. The positions of the two oligonucleotides used for PCR diagnosis of homologous recombination are indicated by the arrows (oligo 1: $3^{\prime}$ end of neo cassette; oligo 2: downstream of SacI site in intron 4). B, BamHI; $H$, Hind III, $X$, XbaI; $S$, SacI.

main of the receptor. This receptor fragment should not bind LDL, and it should not remain associated with the cell membrane since it lacks the membrane spanning segment.

ES cells were electroporated with the linearized targeting vector and subjected to positive and negative selection using standard procedures (36). Homologous recombination events were detected by PCR and verified by digestion of genomic ES cell DNA with BamHI. The presence of a diagnostic 5.5-kb $B a m H I$ fragment in addition to the wild-type $16-\mathrm{kb}$ fragment is indicative of gene targeting when the Southern blot is probed with a genomic DNA fragment located outside of the targeting vector (indicated by the asterisk in Fig. 1). The frequency of homologous recombination was very high. Approximately $50 \%$ of clones that were resistant to both G418 and FIAU exhibited homologous recombination.

Recombinant stem cell clones injected into C57B1 / 6 blastocysts (27) gave rise to chimeric animals with a stem cell-derived coat color contribution that ranged from 30 to $100 \%$. Several male chimeras derived from independently targeted stem cell clones efficiently transmitted the stem cell-derived genome through the germ line. Offspring heterozygous for the disrupted LDL receptor allele were diagnosed by Southern blotting. When heterozygous animals were mated to each other, their offspring included animals that were wild-type $(+1$ $+)$, heterozygous $(+/-)$, and homozygous $(-/-)$ for the disrupted LDL receptor allele. Fig. 2 shows a representative 


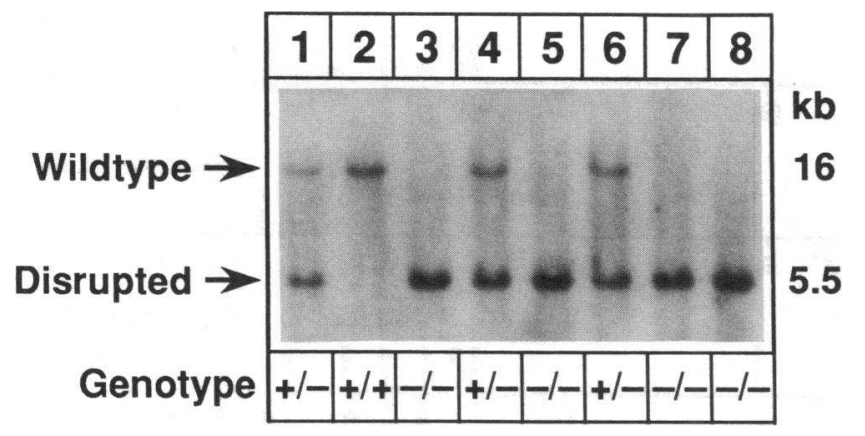

Figure 2. Genotypes of offspring from matings of $L D L R^{+/-}$mice. Male and female mice heterozygous for the disrupted LDL receptor allele $(+/-)$ were mated, and tail DNA from the offspring was analyzed by Southern blotting using a genomic DNA fragment located outside of the targeting construct (denoted by the asterisk in Fig. 1). The genotypes of one litter containing mice that are wild-type $(+/+)$, heterozygous $(+/-)$, or homozygous $(-/-)$ for the disrupted LDL receptor allele are shown. The wild-type allele is represented by a band at $16 \mathrm{~kb}$, while the disrupted allele creates a band at $5.5 \mathrm{~kb}$ when genomic DNA is digested with BamHI (see Fig. 1).

genomic Southern blot that reveals the diagnostic bands for the wild-type and disrupted LDL receptor gene. Of 177 offspring from 28 heterozygous matings, the three genotypes were produced in the ratio of 47:93:37 (Table I), which is consistent with the expected Mendelian ratio of 1:2:1. Homozygous male and female animals were fertile and produced normal-sized litters when mated to each other.

To confirm the inability of the disrupted gene to produce full-length LDL receptors, we prepared liver membranes from wild-type, heterozygous, and homozygous animals. Proteins were solubilized with detergent, and $50 \mu \mathrm{g}$ of each sample were analyzed by SDS gel electrophoresis and immunoblotting with a polyclonal antibody that detects the mouse LDL receptor. As shown in Fig. $3 A$, normal LDL receptor protein was readily detected by the antibody in wild-type $(+/+$, lanes 1 and 4$)$ and in heterozygous animals $(+/-$, lane 2$)$, but was undetectable in animals that were homozygous for the LDL receptor defect $(-/-$, lane 3$)$. An abnormal band (marked by an asterisk) was present in liver membranes prepared from heterozygous (lane

Table I. Plasma Cholesterol Concentrations in Offspring from 28 Matings between $L D L R^{+/-}$Mice

\begin{tabular}{lccc}
\hline & \multicolumn{3}{c}{ Total Plasma Cholesterol Level (mg/dl) } \\
\cline { 2 - 4 } Sex & $+/+$ & $+/-$ & $-/-$ \\
\hline \multirow{2}{*}{ Male } & $119 \pm 4$ & $158 \pm 4$ & $228 \pm 9$ \\
& $(n=19)$ & $(n=39)$ & $(n=16)$ \\
Female & $100 \pm 4^{*}$ & $138 \pm 4^{*}$ & $239 \pm 8$ \\
& $(n=28)$ & $(n=54)$ & $(n=21)$
\end{tabular}

Total plasma cholesterol concentrations were measured from the indicated number $(n)$ of male and female mice (nonfasting) that were wild-type $(+/+)$, heterozygous $(+/-)$, or homozygous $(-/-)$ for a disrupted LDL receptor allele. The 177 mice arose from 28 litters born to crosses between heterozygous males and females. Genotype was determined by Southern blot analysis. Nonfasting blood samples were obtained between 46 and $56 \mathrm{~d}$ of age (mean age, $52 \mathrm{~d}$ ).

* Sex difference, $P=0.01$ (unpaired $t$ test).

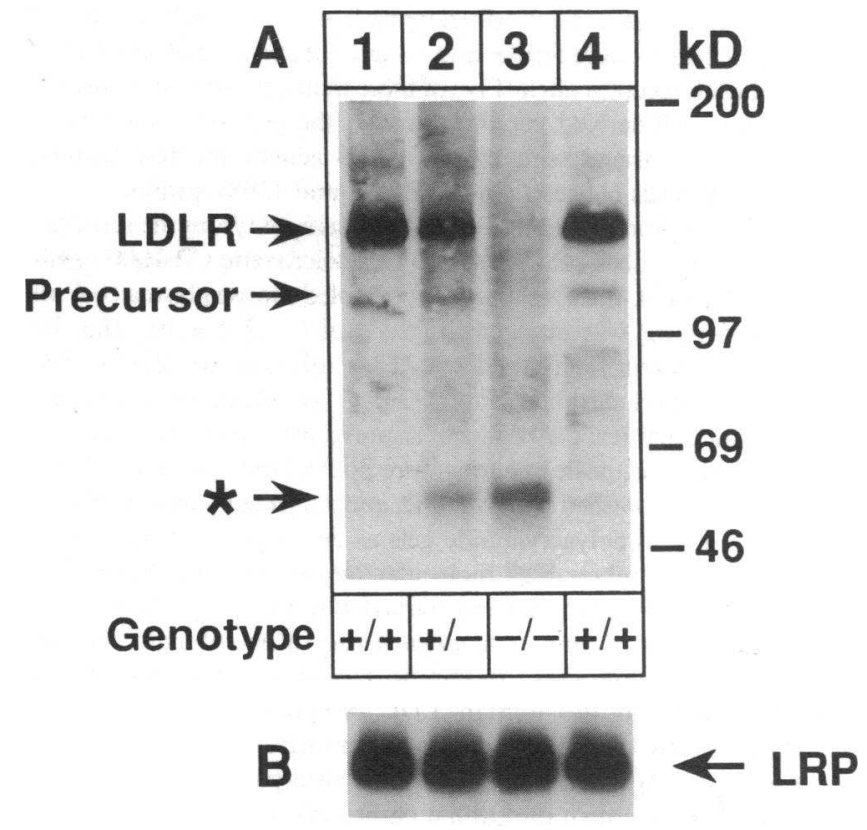

Figure 3. Immunoblot analysis of LDL receptors in liver membranes from mice carrying the disrupted LDL receptor allele. Liver membranes from mice that were wild-type $(+/+$, lanes 1 and 4$)$, heterozygous $(+/-$, lane 2$)$, or homozygous $(-/-$, lane 3$)$ for the disrupted LDL receptor allele were solubilized with Triton X-100 as previously described (51). An aliquot of each sample ( $50 \mu \mathrm{g}$ protein) was subjected to $6.5 \%$ SDS-PAGE under nonreducing conditions, and the proteins were transferred to nitrocellulose filters for immunoblot analysis $(A)$ and ligand blot analysis $(B)$. The filter in $A$ was incubated with $5 \mu \mathrm{g} / \mathrm{ml}$ rabbit anti-LDL receptor $\operatorname{IgG}(37)$, and bound IgG was detected by an immunoperoxidase procedure using the ECL kit (Amersham). The positions of migration of the mature LDL receptor (LDLR) and its precursor are indicated. The immunoreactive protein marked by the asterisk $\left({ }^{*}\right)$ represents the truncated form of the LDL receptor caused by insertion of the neo cassette into exon 4 . The filter in $B$ was incubated with $1 \mu \mathrm{g} / \mathrm{ml}^{125}$ I-labeled recombinant 39-kD fusion protein $\left(10^{6} \mathrm{cpm} / \mathrm{ml}\right)$, which binds to LRP (30). After incubation and washing, the filters in $A$ and $B$ were exposed to Kodak XAR-5 film for $1 \mathrm{~min}$ and $6 \mathrm{~h}$, respectively. Gels were calibrated with high molecular weight markers.

2) and homozygous (lane 3) animals, but was absent in wildtype liver membranes (lanes 1 and 4 ). This latter protein presumably represents the truncated product made from the disrupted allele. Fig. $3 B$ shows that expression of the LRP/ $\alpha_{2} \mathrm{M}$ receptor was not affected by the disruption of the LDL receptor as shown by ligand blotting of an equivalent filter probed with an ${ }^{125}$ I-labeled $39-\mathrm{kD}$ fusion protein that binds to this receptor (30).

Mice heterozygous or homozygous for the disrupted LDL receptor allele have elevated plasma cholesterol levels when compared with their wild-type litter mates. Table I shows total plasma cholesterol levels of mice from 28 litters derived from the mating of heterozygous animals and fed a normal chow diet. The mean age of the animals at the time of measurement was $52 \mathrm{~d}$. Total (nonfasting) plasma cholesterol values are $\sim 35 \%$ elevated in heterozygotes and about two times higher in $L D L R^{-1-}$ mice when compared to wild-type litter mates. In animals of wild-type or heterozygous genotype, females had a lower total plasma cholesterol level than males. This difference was absent in the $L D L R^{-1-}$ mice. There was no significant 
difference in plasma triglyceride concentration among animals of the three genotypes ( $8-10$ animals per group) whose average nonfasting values on a normal chow diet ranged from 119 to $133 \mathrm{mg} / \mathrm{dl}$ (data not shown).

To learn which lipoprotein fraction was affected by the loss of functional LDL receptors in the mouse, we used FPLC to determine the lipoprotein cholesterol profiles of male and female mice of the three different genotypes fed a normal chow diet (Fig. $4 A-C$ ). Plasma of wild-type mice contained very little cholesterol in the IDL/LDL fraction. A small but definite increase in this fraction was observed in heterozygous mice of either sex. Animals homozygous for the LDL receptor defect showed a marked increase almost exclusively in the IDL/LDL fraction with a small increase in VLDL. For all genotypes, the HDL-cholesterol level was slightly higher in male mice as compared with female mice, but there was no dramatic effect of LDL receptor gene disruption.

To estimate the relative elevation of IDL/LDL from the data of Fig. $4 A-C$, we added up the total cholesterol content of each column fraction within the IDL/LDL peak and then expressed the data relative to the levels observed in wild-type mice of the same sex. These data revealed that the IDL/LDL cholesterol was elevated about twofold in $L D L R^{+/-}$mice of either sex and 7.4- to 9-fold in male and female $L D L R^{-1-}$ mice, respectively. The HDL-cholesterol was elevated only modestly ( $\sim 1.3$-fold $)$ in the $L D L R^{-/-}$mice.
Fig. $4 D-F$ shows comparisons of the lipoprotein cholesterol profiles of male mice of the different genotypes fed either a normal chow diet with or without $0.2 \%$ cholesterol $/ 10 \%$ coconut oil. Wild-type mice showed only a small difference in lipoprotein profile in response to the cholesterol-enriched diet. Heterozygous mice responded with a small, but distinct elevation in IDL/LDL cholesterol. In the $L D L R^{-/-}$mice the cholesterol content of the IDL/LDL fraction rose about threefold. The mean total plasma cholesterol levels for the three genotypes before (fasted) and after (nonfasted) cholesterol feeding were as follows: $+/+, 146$ and $149 \mathrm{mg} / \mathrm{dl} ;+/-, 188$ and 196 $\mathrm{mg} / \mathrm{dl}$; and $-/-, 293$ and $425 \mathrm{mg} / \mathrm{dl}$, respectively.

The apoproteins of the various fractions in Fig. $4 D-F$ were analyzed by SDS polyacrylamide gel electrophoresis and Coomassie blue staining (Fig. 5). On the normal chow diet, the heterozygous mice showed a distinct elevation in apo B-100 and apo $E$ in the IDL/LDL fraction. The IDL/LDL fraction from $L D L R^{-1-}$ mice had a much more marked increase of these two apoproteins as well as of apo B-48. The $0.2 \%$ cholesterol $/ 10 \%$ coconut oil diet elicited a pronounced increase in apo B-100, apo B-48, and apo E in the IDL/LDL fraction of the $L D L R^{-1-}$ mice. A small increase in the apo E of VLDL and HDL was also apparent in the cholesterol-fed mice (homozygotes $>$ heterozygotes $>$ wild-type).

To evaluate the functional effect of the LDL receptor deficiency, we compared the ability of $L D L R^{-1-}$ mice and wild-

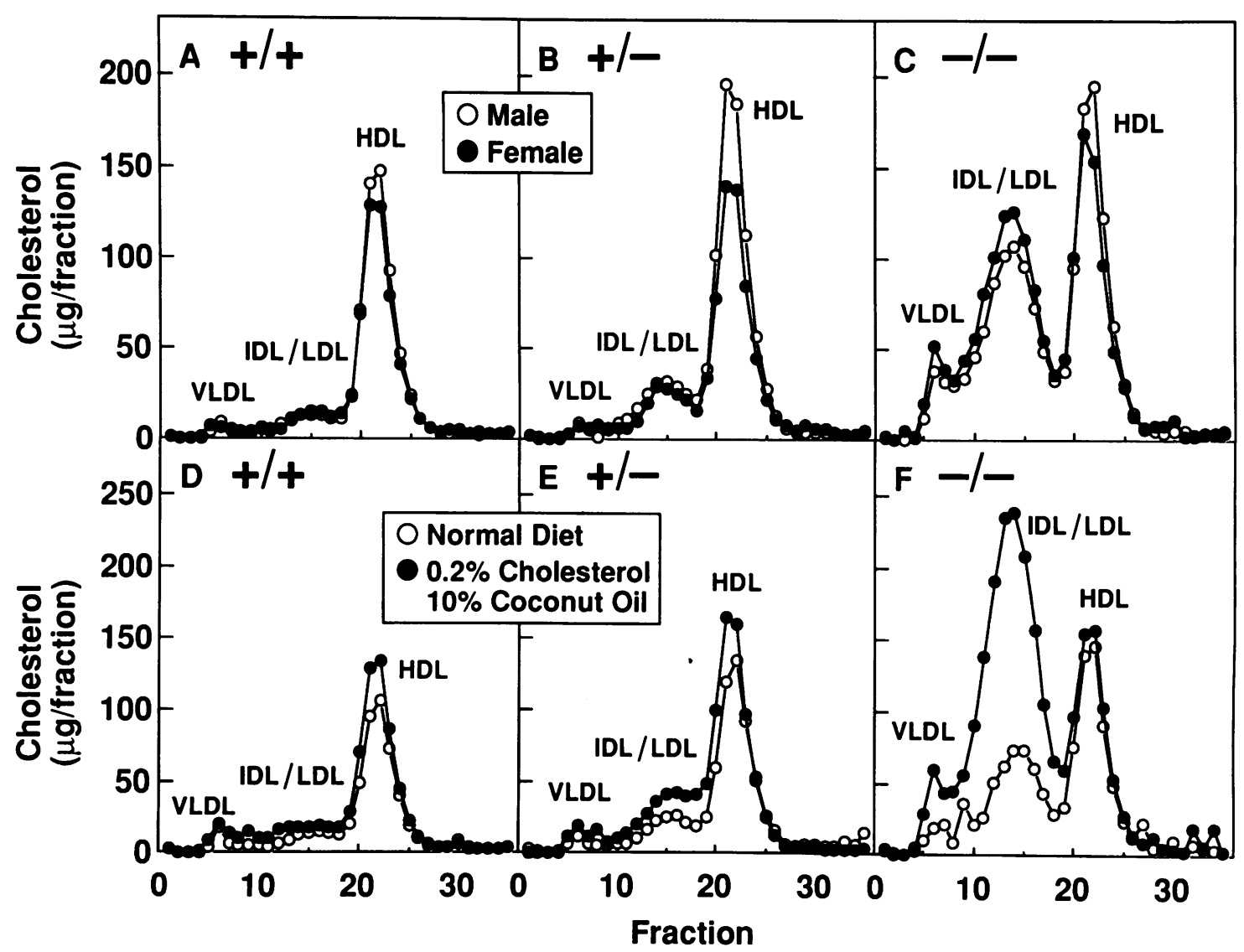

Figure 4. FPLC profiles of mouse plasma lipoproteins from wild-type $(+/+)$ and mutant mice carrying the disrupted LDL receptor allele in heterozygous $(+/-)$ and homozygous $(-/-)$ forms. Mice with the indicated genotype $(n=10$ for each sex in $A-C$ and $n=5$ males in $D-F)$ were fed a normal diet in $A-C$ or the indicated diet in $D-F$ for $7 \mathrm{wk}$. The pooled plasma from each group (collected from 12-h fasted animals in $A-C$ and from nonfasted animals in $D-F$ ) was subjected to gel filtration on FPLC, and the cholesterol content of each fraction was measured as described in Methods. The mice were 8-9 wk of age in $A-C$ and $16-17 \mathrm{wk}$ in $D-F$. 

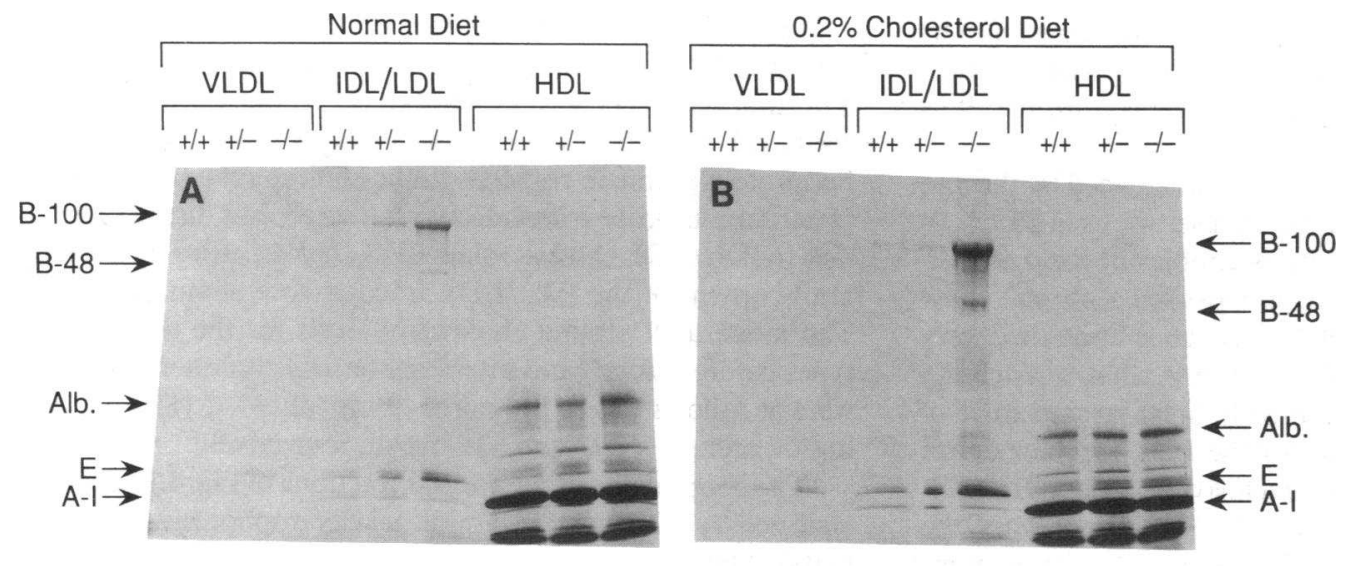

Figure 5. SDS-gel electrophoresis of lipoprotein fractions from wild-type and mutant mice fed different diets. Male mice ( $n=5$ per group) that were wild-type $(+/+)$, heterozygous, $(+/-)$ or homozygous $(-/-)$ for the disrupted LDL receptor allele were fed either a normal diet $(A)$ or a diet containing $0.2 \%$ cholesterol and $10 \%$ coconut oil $(B)$ as described in the legend to Fig. 4. The apoproteins from the VLDL, IDL/LDL, and HDL containing fractions in Fig. 4 (equivalent to $70 \mu \mathrm{l}$ of plasma) were subjected to electrophoresis on 3-15\% SDS gradient gels. Proteins were stained with Coomassie blue. The positions of migration of apo B-100, apo B-48, albumin (Alb.), apo E, and apo A-I are indicated.

type mice to clear ${ }^{125}$ I-labeled lipoproteins from the circulation (Fig. 6). For this purpose, we isolated three lipoprotein fractions (VLDL, LDL, and HDL) by ultracentrifugation of pooled plasma of $50 \mathrm{LDLR}^{-/-}$mice. After radiolabeling with ${ }^{125} \mathrm{I}$, each lipoprotein was injected into the external jugular vein of three wild-type $(+/+)$ and three homozygous $(-/-)$ animals. Blood was obtained at the indicated intervals, and the radioactivity was expressed relative to the radioactivity at 2 min after injection of the label. As shown in Fig. $6 \mathrm{~A}$, wild-type mice (open circles) clear ${ }^{125} \mathrm{I}-\mathrm{VLDL}$ much more efficiently than $L D L R^{-1-}$ animals (closed circles). In the wild-type ani-
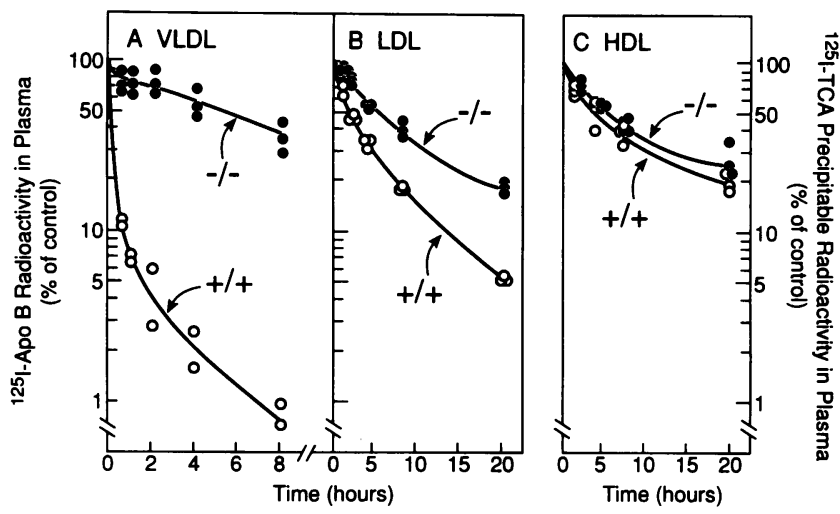

Figure 6. Disappearance of ${ }^{125}$ I-labeled lipoproteins from the circulation in wild-type (O) and $L D L R^{-1-}(\bullet)$ mice. For each graph, 3 wild-type and $3 L D L R^{-1-}$ male mice, 20-24 wk of age that had been fasted for $12 \mathrm{~h}$, were anesthetized with sodium pentobarbital $(60$ $\mathrm{mg} / \mathrm{kg}$ ). Each mouse received an intravenous bolus via the external jugular vein of $0.25 \mathrm{ml}$ of $0.15 \mathrm{M} \mathrm{NaCl}$ containing bovine serum albumin $(2 \mathrm{mg} / \mathrm{ml})$ and one of the following ${ }^{125}$ I-labeled mouse lipoproteins: $15 \mu \mathrm{g}$ protein of ${ }^{125} \mathrm{I}-\mathrm{VLDL}(2,500 \mathrm{cpm} / \mathrm{ng}$ protein $), 15 \mu \mathrm{g}$ protein of ${ }^{125} \mathrm{I}$-LDL $(1,110 \mathrm{cpm} / \mathrm{ng}$ protein $)$, or $15 \mu \mathrm{g}$ protein of ${ }^{125} \mathrm{I}$ HDL ( $491 \mathrm{cpm} / \mathrm{ng}$ protein). Blood was collected at the indicated time by retro-orbital puncture. In $A$ and $B$, the plasma content of ${ }^{125}$ I-labeled apo B was measured by isopropanol precipitation followed by gamma counting $(10,52)$. In $C$, the plasma content of trichloroacetic acid-precipitable ${ }^{125}$ I-radioactivity was measured. The " $100 \%$ of control" represents the average value for plasma ${ }^{125}$ I-radioactivity in the wild-type and mutant mice at 2 min after injection. One wild-type animal in $A$ died $\sim 30 \mathrm{~min}$ after the intravenous injection. mals $50 \%$ of the radioactivity had been eliminated within 10 min, and this was prolonged to $5 \mathrm{~h}$ in the $L D L R^{-/-}$mice. The clearance of ${ }^{125} \mathrm{I}-\mathrm{LDL}$ was also retarded in the $L D L R^{-/-}$animals (half-time for disappearance, $5 \mathrm{~h}$ in the $L D L R^{-1-}$ mice $v s .2 \mathrm{~h}$ in the wild-type animals) (Fig. $6 \mathrm{~B}$ ). The clearance of ${ }^{125} \mathrm{I}$-HDL (half-time of $5.5 \mathrm{~h}$ ) was not affected by the receptor deficiency (Fig. $6 \mathrm{C}$ ).

In order to determine whether adenovirus-mediated gene transfer of the human LDL receptor can reverse the abnormalities caused by the knockout of the LDL receptor, we injected 2 $\times 10^{9} \mathrm{pfu}$ of recombinant virus containing either the luciferase cDNA (AdCMV-Luc) or the LDL receptor CDNA (AdCMVLDLR) into $L D L R^{-1-}$ mice. This dose has been found previously to cause expression of the foreign gene in the majority of hepatocytes (23). $4 \mathrm{~d}$ after administration of the recombinant viruses, liver membrane proteins were prepared from the individual animals and separated by SDS gel electrophoresis (Fig. 7). Lane 1 shows an immunoblot of a wild-type mouse liver,

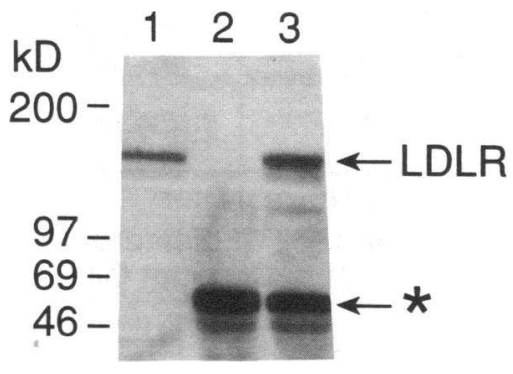

Figure 7. Immunoblot analysis of LDL receptors in liver membranes from $L D L R^{-1-}$ mice $4 \mathrm{~d}$ after injection of recombinant adenovirus expressing the human LDL receptor cDNA. Male mice homozygous for the disrupted LDL receptor allele, $17 \mathrm{wk}$ of age, were injected intravenously with $2 \times 10^{9} \mathrm{pfu}$ of adenovirus containing either the luciferase cDNA (lane 2) or the human LDL receptor cDNA (lane 3 ) as described in Methods. $4 \mathrm{~d}$ after administration of the virus, the animals were killed, and liver membranes were prepared from single mice, subjected to SDS gel electrophoresis under reducing conditions ( $5 \%$ [ vol/vol] 2-mercaptoethanol), and transferred to filters for immunoblot analysis with a rabbit anti-LDL receptor IgG as described in the legend to Fig. 3. Lane 1 contains liver membrane proteins from a wild-type mouse not injected with recombinant adenovirus. The position of migration of the mature LDL receptor (LDLR) is indicated by the arrow. The immunoreactive protein marked by the asterisk $\left({ }^{*}\right)$ represents the truncated form of the LDL receptor caused by insertion of the neo cassette into exon 4 . 
revealing the normal mouse LDL receptor. As expected, no intact LDL receptor protein is detectable by immunoblotting in the liver of an $L D L R^{-1-}$ mouse injected with the luciferasecontaining control virus (lane 2). In contrast, injection of AdCMV-LDLR led to high-level expression of the intact receptor in the liver of an $L D L R^{-1-}$ mouse (lane 3).

Fig. 8 shows an immunohistochemical analysis of LDL receptor expression in the livers of $L D L R^{-1-}$ mice $4 \mathrm{~d}$ after injection of AdCMV-Luc $(A)$ or AdCMV-LDLR $(B)$. In animals injected with the luciferase-containing virus, there were no detectable LDL receptors $(A)$. In the mice injected with AdCMV-LDLR the majority of cells showed positive immunofluorescence $(B)$. The enhanced magnification in $C$ shows that the virally encoded receptor was expressed in a polarized fashion on the blood-sinusoidal surface of the hepatocyte, as is the human LDL receptor in transgenic mice (21).

To test the function of the adenovirus-encoded receptor, we measured the clearance of ${ }^{125}$ I-labeled VLDL (Fig. 9). For this experiment we used VLDL isolated from WHHL rabbits, which are deficient in functional LDL receptors. In preliminary experiments we found that ${ }^{125}$ I-labeled VLDL from WHHL rabbits is cleared from the circulation of normal mice approximately as rapidly as ${ }^{125}$ I-labeled mouse VLDL, and the rabbit lipoprotein is much easier to obtain. $L D L R^{-/-}$mice that received recombinant adenovirus encoding the human LDL receptor cleared the ${ }^{125}$ I-labeled rabbit VLDL from their plasma at a rapid rate (Fig. 9). In contrast, mice that had received the luciferase-containing virus cleared the ${ }^{125}$ I-VLDL at a rate that was similar to that of uninjected animals (compare with Fig. $6 \mathrm{~A}$ ).

We next sought to determine whether the adenovirus-encoded receptors could normalize the lipoprotein profile of $L D L R^{-1-}$ mice. For this purpose we injected the control virus (AdCMV-Luc) or the LDL receptor-containing virus (AdCMV-LDLR) into $L D L R^{-1-}$ male mice ( 3 animals per group). $4 \mathrm{~d}$ after injection the animals were exsanguinated, the pooled plasma of each group was subjected to FPLC gel filtration, and the cholesterol content of the fractions was plotted (Fig. 10). The lipoprotein profile of the mice that had been injected with the luciferase-containing virus closely resembled the profile of uninjected animals (compare with Fig. 4). In the group that had received the LDL receptor-containing virus, the IDL/LDL peak disappeared, and there was a slight increase in VLDL-cholesterol.

\section{Discussion}

The current results demonstrate that elimination of functional LDL receptor genes by homologous recombination profoundly elevates IDL and LDL levels in mice and that these abnormalities can be reversed postnatally by adenovirus-mediated transfer of a gene encoding the LDL receptor. The experiments establish a new animal model by which to explore genetic and environmental factors that interact with LDL receptors to control cholesterol levels. They also provide a new model system in which to study somatic cell gene therapy targeted at the liver.

The most profound functional change observed in the current study was the marked reduction in the clearance rate of ${ }^{125}$ I-labeled VLDL from plasma in the homozygous $L D L R^{-/-}$ mice. The time required for clearance of $50 \%$ of the injected lipoprotein rose from $10 \mathrm{~min}$ to $300 \mathrm{~min}$, a 30 -fold change. These data indicate that the LDL receptor is responsible for most of the rapid clearance of VLDL remnants and IDL from plasma of mice. The exact proportion cleared by the LDL receptor may be overestimated in these studies because the labeled VLDL was prepared from LDL receptor-deficient animals, i.e., $L D L R^{-1-}$ mice or homozygous WHHL rabbits. Although these particles float in the VLDL density range $(d$ $<1.006 \mathrm{~g} / \mathrm{ml}$ ), they are likely to represent partially metabolized VLDL particles that have overaccumulated in the donor animals because of the LDL receptor deficiency. Any VLDL particle that is rapidly cleared from plasma in the receptor-deficient animals would be underrepresented in the sample that is used for labeling. This would include large apo E-rich VLDL particles containing either apo B-48 or apo B-100, which may be cleared in part by the chylomicron remnant receptor (38). This problem of underrepresentation of rapidly cleared particles is a problem with all lipoprotein clearance studies (see Discussion in reference 38). Despite these limitations, the data indicate clearly that the VLDL fraction of mice contains a substantial number of particles that are normally cleared by the LDL receptor, presumably owing to their content of apo $E$. In LDL receptor deficiency states, these particles remain in plasma for long periods and are presumably converted to LDL. Although such conversion was not studied in the current study, it was previously demonstrated in WHHL rabbits $(10,39)$.

Striking parallels exist between the findings in the current study of $L D L R^{-1-}$ mice and previous studies of lipoprotein clearance in homozygous WHHL rabbits $(10,39)$ and FH homozygotes (9). In all three species the most profound abnormality involves the clearance of VLDL remnants and IDL. In WHHL rabbits, the half-time for VLDL clearance was extended from 12 to $480 \mathrm{~min}(10)$, a result that parallels the 10 to 300 min change in the current study. In a study of ${ }^{125}$ I-VLDL turnover in FH homozygotes, Soutar et al. (9) observed a sevenfold decrease in the clearance of ${ }^{125} \mathrm{I}$-IDL derived from ${ }^{125} \mathrm{I}$ VLDL (fractional turnover rate $0.48 / \mathrm{h}$ in normal subjects $v s$. $0.064 / \mathrm{h}$ in FH homozygotes). Using a more complex kinetic analysis, James et al. (43) also found a decreased clearance of VLDL remnants and IDL. This indicates that a major function of the LDL receptor in all three species is the clearance of remnant particles derived from VLDL, thereby preventing their conversion into LDL.

The relative decline in LDL clearance observed in LDL receptor-deficient mice (2.5-fold) also correlates well with observations in WHHL rabbits. Yamada et al. (39) observed a reduction of 2-fold, Pittman et al. (40) 2.6-fold, and Spady et al. (41) 3.5-fold. In FH homozygotes the reduction in LDL clearance is also about threefold $(42,43)$. These data indicate that about $60 \%$ of LDL particles are normally cleared by the LDL receptor in mice. The residual clearance of $L D L$ observed in the absence of LDL receptors is likely to be mediated by another receptor with a lower affinity for LDL. Like the LDL receptor, this alternate receptor functions primarily in the liver (40).

The absolute level of plasma LDL-cholesterol in the $L D L R^{-1-}$ mice is much lower than that observed in WHHL rabbits or FH homozygotes. Although we did not measure LDL-cholesterol quantitatively, it is apparent from the FPLC profiles that the IDL/LDL peak contains $\sim 50 \%$ of the total cholesterol in the plasma of the $L D L R^{-/-}$mice, which would indicate an IDL/LDL-cholesterol level of $\sim 130 \mathrm{mg} / \mathrm{dl}$. This contrasts with LDL-cholesterol levels above $450 \mathrm{mg} / \mathrm{dl}$ in WHHL rabbits $(10,44)$ and FH homozygotes (2). This differ- 

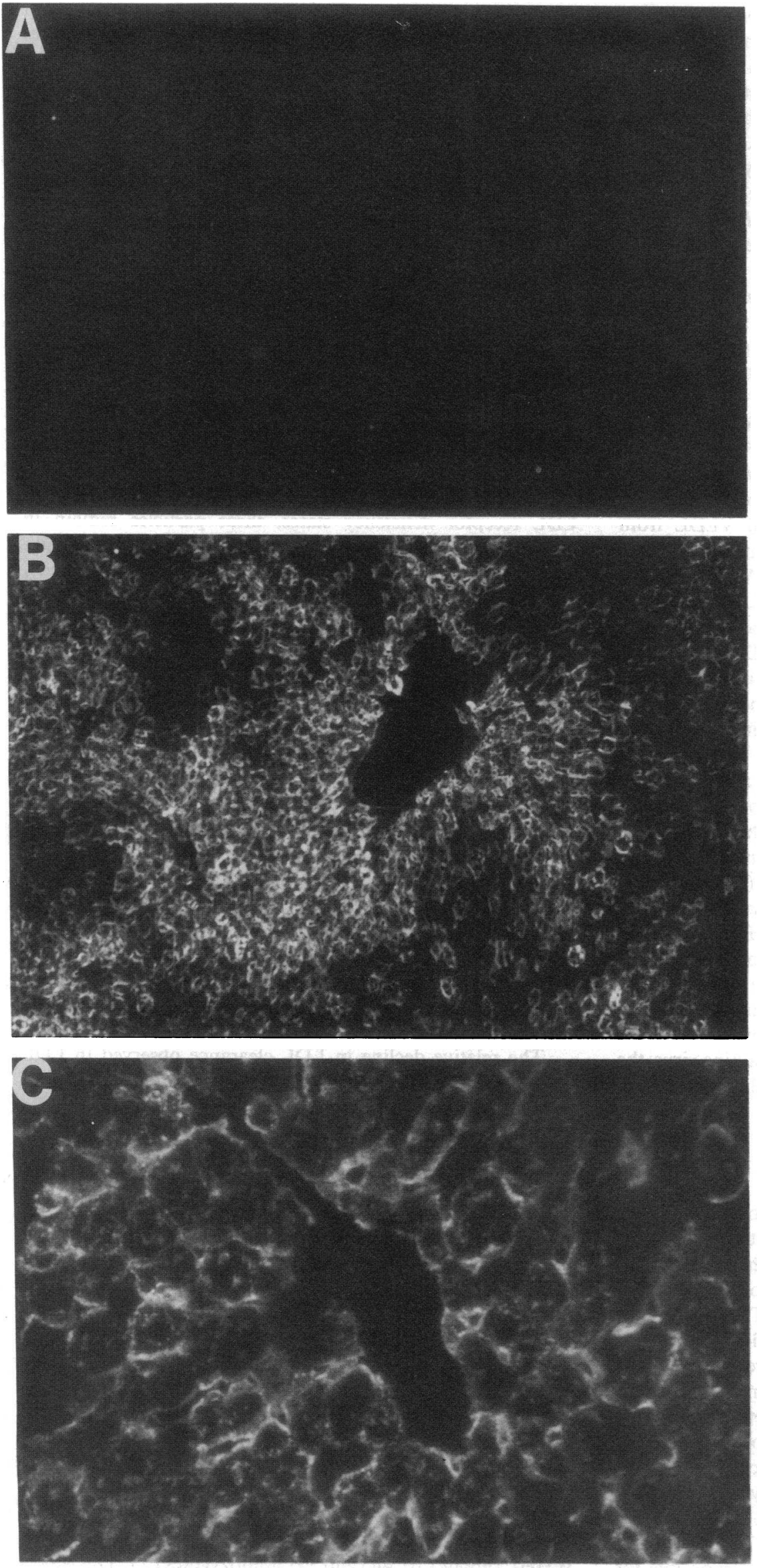

Figure 8. Immunohistochemical staining of LDL receptors in the liver of an $L D L R^{-/-}$ mouse after treatment with recombinant adenovirus expressing the human LDL receptor cDNA. Male mice homozygous for the disrupted LDL receptor allele, 18 wk of age, were injected intravenously with $2 \times 10^{9} \mathrm{pfu}$ of either AdCMV-Luciferase $(A)$ or AdCMVLDLR ( $B$ and $C$ ) as described in Methods. Four days after administration of the virus, the livers were removed for immunohistochemistry. Frozen sections were incubated with $20 \mu \mathrm{g} / \mathrm{ml}$ of rabbit polyclonal anti-LDL receptor antibody, and bound IgG was detected with $5 \mu \mathrm{g} / \mathrm{ml}$ FITC-labeled goat anti-rabbit IgG as described in Methods. Magnification, $A$ and $B, \times 25 ; C, \times 100$. 


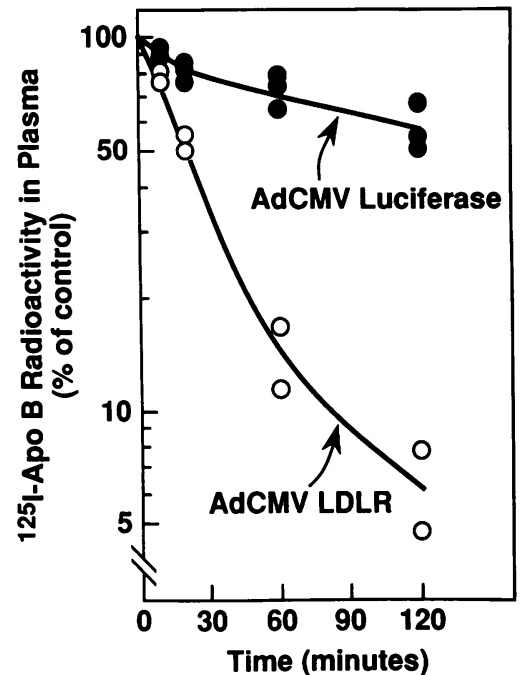

Figure 9. Disappearance of ${ }^{125}$ I-VLDL from the circulation of $L D L R^{-/-}$ mice after treatment with recombinant adenovirus expressing the human LDL receptor cDNA. Three male mice homozygous for the disrupted LDL receptor allele, $19 \mathrm{wk}$ of age, were injected intravenously with $2 \times 10^{9}$ pfu of either AdCMVLDLR (O) or AdCMV-Luciferase (•). $4 \mathrm{~d}$ after administration of the virus, the animals (nonfasted) were injected with 15 $\mu \mathrm{g}$ protein of ${ }^{125}$ I-labeled VLDL ( $308 \mathrm{cpm} / \mathrm{ng}$ protein) isolated from WHHL rabbits. Blood was collected at the indicated time by retro-orbital puncture, and the plasma content of ${ }^{125}$ I-labeled apo B was measured by isopropanol precipitation $(10,52)$. The " $100 \%$ of control" represents the average value for plasma ${ }^{125}$ I-radioactivity 1 min after injection. One animal injected with AdCMV-LDLR died $\sim 10$ min after injection of the ${ }^{125}$ I-VLDL.

ence might be explained by the production of VLDL containing apo B-48 in livers of mice, but not rabbits or humans. About $70 \%$ of the apo B mRNA in the livers of adult mice encodes the apo B-48 isoform (14). Remnants derived from apo B-48 containing VLDL might be cleared relatively rapidly by the livers of the $L D L R^{-1-}$ mice, owing to the ability of the

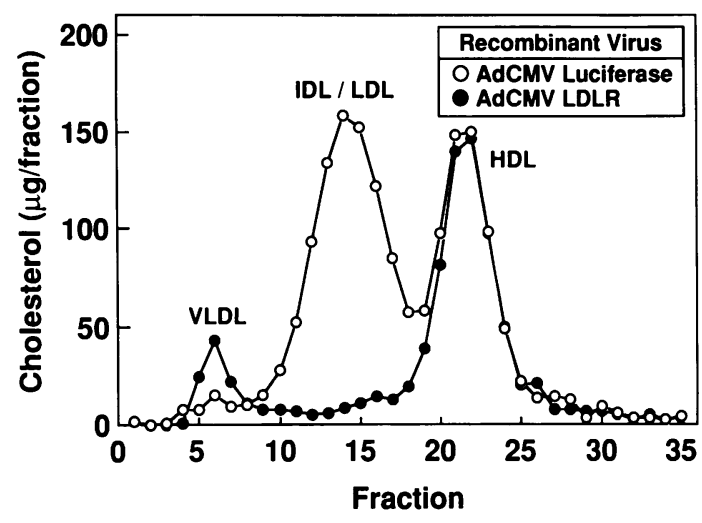

Figure 10. FPLC profiles of plasma lipoproteins from $L D L R^{-1-}$ mice after treatment with recombinant adenovirus expressing the human LDL receptor cDNA. Three male mice homozygous for the LDL receptor disrupted allele, $17 \mathrm{wk}$ of age, were injected with $2 \times 10^{9} \mathrm{pfu}$ of adenovirus containing either the luciferase cDNA $(0)$ or the human LDL receptor CDNA $(\bullet) .4 \mathrm{~d}$ after administration of the virus, blood was collected from the animals (nonfasted), and the plasma from the three animals in each group was pooled and subjected to gel filtration on FPLC. The cholesterol content of each fraction was determined as described in Methods. The mean total plasma cholesterol levels in the two groups of mice were $279 \mathrm{mg} / \mathrm{dl}(\mathrm{O})$ and 139 $\mathrm{mg} / \mathrm{dl}(\bullet)$. apo E/apo B-48 particles to bind to chylomicron remnant receptors, thereby leading to lower levels of LDL.

The hypothesized role of apo E/apo B-48 particles is supported by a comparison of the current data with those of Zhang et al. (45) and Plump et al. (46), who eliminated the gene for apo $\mathrm{E}$ in mice using a similar homologous recombination technique. Apo $\mathrm{E}^{-1-}$ mice had total plasma cholesterol levels of $400-500 \mathrm{mg} / \mathrm{dl}$, nearly all of which was contained in particles with the size of VLDL and VLDL remnants. The level of apo B-48 in plasma was also markedly elevated (45). The severity of this abnormality in comparison with the effects of LDL receptor deficiency supports the notion that apo $\mathrm{E}$ binds to two receptors, the LDL receptor and the chylomicron remnant receptor. Knockout of apo E therefore has a more profound effect on lipoprotein clearance than knockout of the LDL receptor in mice.

In humans the opposite is true, i.e., LDL receptor deficiency raises the total plasma cholesterol more than does apo $\mathrm{E}$ deficiency. Receptor-negative $\mathrm{FH}$ homozygotes have total plasma cholesterol levels of $700-1,000 \mathrm{mg} / \mathrm{dl}(2)$, whereas individuals with an absence of apo $E$ have plasma cholesterol levels of 443 to $614 \mathrm{mg} / \mathrm{dl}$ (47). This is likely due, in part, to the fact that human livers do not produce apo B-48 and that apo E accelerates the removal of apo B-100 containing VLDL remnants primarily by binding to only one receptor, namely, the LDL receptor.

LDL receptors are believed to constitute an important defense against the cholesterol-elevating effect of dietary cholesterol (1). In rabbits (48) and hamsters (49), dietary cholesterol elevates plasma LDL-cholesterol levels in part by suppressing LDL receptors. In the current study, LDL receptor-deficient mice responded to the $0.2 \%$ cholesterol / $10 \%$ coconut oil diet with a rise in plasma LDL-cholesterol that was much greater than was observed in wild-type mice. There was also a definite increase in the amounts of apo B-100 and apo E in plasma, particularly in the IDL/LDL fraction (Fig. 5). Thus, when LDL receptors are already absent as a result of genetic elimination, mice become hyperresponsive to dietary cholesterol.

The current experiments with recombinant adenovirus demonstrate that this vector can restore LDL receptor expression within $4 \mathrm{~d}$ in an LDL receptor-deficient mouse. However, many technical problems would have to be overcome before such therapy could be considered for humans. First, it is unknown whether or not the expression of adenovirus-encoded genes in liver will persist for long periods. The genome of the defective virus does not replicate, nor does it integrate into the genome at any appreciable frequency. On the other hand, Stratford-Perricaudet et al. (24) did note persistent expression for a year after injection of the virus into neonatal animals lacking ornithine transcarbamylase activity. Second, adenovirus-encoded proteins are likely to be the targets of immune reactions. Mice are known to develop an immune response to adenoviral proteins (50), which might hamper its use for long periods in these animals. Nearly all humans are expected to possess antibodies against adenovirus, and these might prevent use of this vector in people. Despite these reservations about human applicability, the adenovirus vector is a useful experimental tool to change the expression of genes acutely in the liver. In the current studies, we used it to reveal the type of result to be expected when more applicable long-term gene delivery methods have been developed. 


\section{Acknowledgments}

We thank Phil Soriano for expert advice and help. Scott Clark, Lucy Lundquist, Wen-Ling Niu, and Sadeq Hassan provided excellent technical assistance.

This work was supported by National Institutes of Health grants HL-20948 and HL-17669, and by grants from the Moss Heart Foundation and the Perot Family Foundation. S. Ishibashi is the recipient of a postdoctoral fellowship from the Sasakawa Health Science Foundation, Tokyo, Japan. R. D. Gerard is an Established Investigator of the American Heart Association. J. Herz is supported by the Syntex Scholar Program and is a Lucille P. Markey Scholar.

Note added in proof. The LDL receptor-deficient mice described in this paper will become available in September 1993 from Jackson Laboratories, 600 Main Street, Bar Harbor, ME 04609.

\section{References}

1. Brown, M. S., and J. L. Goldstein. 1986. A receptor-mediated pathway for cholesterol homeostasis. Science (Wash. DC). 232:34-47.

2. Goldstein, J. L., and M. S. Brown. 1989. Familial hypercholesterolemia. In The Metabolic Basis of Inherited Disease. C. R. Scriver, A. L. Beaudet, W. S. Sly, and D. Valle, editors. McGraw-Hill Publishing Co., New York, 1215-1250.

3. Mahley, R. W. 1988. Apolipoprotein E: Cholesterol transport protein with expanding role in cell biology. Science (Wash. DC). 240:622-630.

4. Brown, M. S., J. Herz, R. C. Kowal, and J. L. Goldstein. 1991. The lowdensity lipoprotein receptor-related protein: double agent or decoy? Curr. Opin. in Lipidol. 2:65-72.

5. Ji, Z.-S., W. J. Brecht, D. Miranda, M. M. Hussain, T. L. Innerarity, and R. W. Mahley. 1993. Role of heparan sulfate proteoglycans in the binding and uptake of apolipoprotein E-enriched remnant lipoproteins by cultured cells. $J$. Biol. Chem. 268:10160-10167.

6. Hobbs, H. H., M. S. Brown, and J. L. Goldstein. 1992. Molecular genetics of the LDL receptor gene in familial hypercholesterolemia. Hum. Mutat. 1:445466.

7. Watanabe, Y., T. Ito, and M. Shiomi. 1985. The effect of selective breeding on the development of coronary atherosclerosis in WHHL rabbits. An animal model for familial hypercholesterolemia. Atherosclerosis. 56:71-97.

8. Scanu, A. M., A. Khalil, L. Neven, M. Tidore, G. Dawson, D. Pfaffinger, E. Jackson, K. D. Carey, H. C. McGill, and G. M. Fless. 1988. Genetically determined hypercholesterolemia in a rhesus monkey family due to a deficiency of the LDL receptor. J. Lipid Res. 29:1671-1681.

9. Soutar, A. K., N. B. Myant, and G. R. Thompson. 1982. The metabolism of very low density and intermediate density lipoproteins in patients with familial hypercholesterolaemia. Atherosclerosis. 43:217-231.

10. Kita, T., M. S. Brown, D. W. Bilheimer, and J. L. Goldstein. 1982. Delayed clearance of very low density and intermediate density lipoproteins with enhanced conversion to low density lipoprotein in WHHL rabbits. Proc. Natl. Acad. Sci. USA. 79:5693-5697.

11. Hobbs, H. H., E. Leitersdorf, C. C. Leffert, D. R. Cryer, M. S. Brown, and J. L. Goldstein. 1989. Evidence for a dominant gene that suppresses hypercholesterolemia in a family with defective low density lipoprotein receptors. J. Clin. Invest. 84:656-664.

12. Lamon-Fava, S., D. Jimenez, J. C. Christian, R. R. Fabsitz, T. Reed, D. Carmelli, W. P. Castelli, J. M. Ordovas, P. W. F. Wilson, and E. J. Schaefer. 1991 The NHLBI twin study: heritability of apolipoprotein A-I, B, and low density lipoprotein subclasses and concordance for lipoprotein(a). Atherosclerosis. 91:97-106.

13. Spady, D. K., L. A. Woollett, and J. M. Dietschy. 1993. Regulation of plasma LDL-cholesterol levels by dietary cholesterol and fatty acids. Annu. Rev. Nutr. 13:355-381

14. Higuchi, K., K. Kitagawa, K. Kogishi, and T. Takeda. 1992. Developmental and age-related changes in apolipoprotein B mRNA editing in mice. J. Lipid Res. 33:1753-1764.

15. Scott, J. 1989. The molecular and cell biology of apolipoprotein-B. Mol. Biol. Med. 6:65-80.

16. Chan, L. 1992. Apolipoprotein B, the major protein component of triglyceride-rich and low density lipoproteins. J. Biol. Chem. 267:25621-25624.

17. Van't Hooft, F. M., D. A. Hardman, J. P. Kane, and R. J. Havel. 1982. Apolipoprotein B (B-48) of rat chylomicrons is not a precursor of the apolipoprotein of low density lipoproteins. Proc. Natl. Acad. Sci. USA. 79:179-182.

18. Chowdhury, J. R., M. Grossman, S. Gupta, N. R. Chowdhury, J. R. Baker, Jr., and J. M. Wilson. 1991. Long-term improvement of hypercholesterolemia after ex vivo gene therapy in LDLR-deficient rabbits. Science (Wash. DC). 254:1802-1805.

19. Wilson, J. M., M. Grossman, C. H. Wu, N. R. Chowdhury, G. Y. Wu, and
J. R. Chowdhury. 1992. Hepatocyte-directed gene transfer in vivo leads to transient improvement of hypercholesterolemia in low density lipoprotein receptordeficient rabbits. J. Biol. Chem. 267:963-967.

20. Hofmann, S. L., D. W. Russell, M. S. Brown, J. L. Goldstein, and R. E. Hammer. 1988. Overexpression of low density lipoprotein (LDL) receptor eliminates LDL from plasma in transgenic mice. Science (Wash. DC). 239:12771281.

21. Pathak, R. K., M. Yokode, R. E. Hammer, S. L. Hofmann, M. S. Brown, J. L. Goldstein, and R. G. W. Anderson. 1990. Tissue-specific sorting of the human LDL receptor in polarized epithelia of transgenic mice. J. Cell Biol. 111:347-359.

22. Yokode, M., R. E. Hammer, S. Ishibashi, M. S. Brown, and J. L. Goldstein. 1990. Diet-induced hypercholesterolemia in mice: Prevention by overexpression of LDL receptors. Science (Wash. DC). 250:1273-1275.

23. Herz, J., and R. D. Gerard. 1993. Adenovirus-mediated low density lipoprotein receptor gene transfer accelerates cholesterol clearance in normal mice. Proc. Natl. Acad. Sci. USA. 90:2812-2816.

24. Stratford-Perricaudet, L. D., M. Levrero, J.-F. Chasse, M. Perricaudet, and P. Briand. 1990. Evaluation of the transfer and expression in mice of an enzyme-encoding gene using a human adenovirus vector. Hum. Gene Ther. $1: 241-256$

25. Capecchi, M. R. 1989. Altering the genome by homologous recombination. Science (Wash. DC). 244:1288-1292.

26. Smithies, O. 1991. Altering genes in animals and humans. In Etiology of Human Disease at the DNA Level. J. Lindsten and U. Pettersson, editors. Raven Press, New York. 221-259.

27. Bradley, A. 1987. Production and analysis of chimaeric mice. In Teratocarcinomas and Embryonic Stem Cells: A Practical Approach. E. J. Robertson, editor. IRL Press, Oxford, UK/Washington, DC. 113-151.

28. Sambrook, J., E. F. Fritsch, and T. Maniatis. 1989. Molecular cloning: A Laboratory Manual. Cold Spring Harbor Laboratory Press, Cold Spring Harbor, New York.

29. Yokode, M., R. K. Pathak, R. E. Hammer, M. S. Brown, J. L. Goldstein, and R. G. W. Anderson. 1992. Cytoplasmic sequence required for basolateral targeting of LDL receptor in livers of transgenic mice. J. Cell Biol. 117:39-46.

30. Willnow, T. F., J. L. Goldstein, K. Orth, M. S. Brown, and J. Herz. 1992. Low density lipoprotein receptor-related protein (LRP) and gp330 bind similar ligands, including plasminogen activator-inhibitor complexes and lactoferrin, an inhibitor of chylomicron remnant clearance. J. Biol. Chem. 267:26172-26180.

31. Goldstein, J. L., S. K. Basu, and M. S. Brown. 1983. Receptor-mediated endocytosis of LDL in cultured cells. Methods Enzymol. 98:241-260.

32. Yamamoto, T., C. G. Davis, M. S. Brown, W. J. Schneider, M. L. Casey, J. L. Goldstein, and D. W. Russell. 1984. The human LDL receptor: A cysteinerich protein with multiple Alu sequences in its mRNA. Cell. 39:27-38.

33. Mehta, K. D., W.-J. Chen, J. L. Goldstein, and M. S. Brown. 1991. The low density lipoprotein receptor in Xenopus laevis. I. Five domains that resemble the human receptor. J. Biol. Chem. 266:10406-10414.

34. Soriano, P., C. Montgomery, R. Geske, and A. Bradley. 1991. Targeted disruption of the c-src proto-oncogene leads to osteopetrosis in mice. Cell. 64:693-702.

35. Mansour, S. L., K. R. Thomas, and M. R. Capecchi. 1988. Disruption of the proto-oncogene int-2 in mouse embryo-derived stem cells: a general strategy for targeting mutations to non-selectable genes. Nature (Lond.). 336:348-352.

36. McMahon, A. P., and A. Bradley. 1990. The Wnt-1 (int-1) proto-oncogene is required for development of a large region of the mouse brain. Cell. 62:1073-1085

37. Russell, D. W., W. J. Schneider, T. Yamamoto, K. L. Luskey, M. S. Brown, and J. L. Goldstein. 1984. Domain map of the LDL receptor: sequence homology with the epidermal growth factor precursor. Cell. 37:577-585.

38. Yamada, N., D. M. Shames, K. Takahashi, and R. J. Havel. 1988. Metabolism of apolipoprotein B-100 in large very low density lipoproteins of blood plasma. J. Clin. Invest. 82:2106-2113.

39. Yamada, N., D. M. Shames, and R. J. Havel. 1987. Effect of LDL receptor deficiency on the metabolism of apolipoprotein B-100 in blood plasma: kinetic studies in normal and Watanabe heritable hyperlipidemic rabbits. J. Clin. Invest. 80:507-515.

40. Pittman, R. C., T. E. Carew, A. D. Attie, J. L. Witztum, Y. Watanabe, and D. Steinberg. 1982. Receptor-dependent and receptor-independent degradation of low density lipoprotein in normal rabbits and in receptor-deficient mutant rabbits. J. Biol. Chem. 257:7994-8000.

41. Spady, D. K., M. Huettinger, D. W. Bilheimer, and J. M. Dietschy. 1987 Role of receptor-independent low density lipoprotein transport in the maintenance of tissue cholesterol balance in the normal and WHHL rabbit. J. Lipid Res. 28:32-41.

42. Bilheimer, D. W., N. J. Stone, and S. M. Grundy. 1979. Metabolic studies in familial hypercholesterolemia: evidence for a gene-dosage effect in vivo. $J$. Clin. Invest. 64:524-533.

43. James, R. W., B. Martin, D. Pometta, J. C. Fruchart, P. Duriez, P. Fuchois, J. P. Farriaux, A. Tacquet, T. Demant, R. J. Clegg, A. Munro, M. F. Oliver 
et al. 1989. Apolipoprotein B metabolism in homozygous familial hypercholesterolemia. J. Lipid Res. 30:159-169.

44. Havel, R. J., T. Kita, L. Kotite, J. P. Kane, R. L. Hamilton, J. L. Goldstein, and M. S. Brown. 1982. Concentration and composition of lipoproteins in blood plasma of WHHL rabbits. Arteriosclerosis. 3:467-474.

45. Zhang, S. H., R. L. Reddick, J. A. Piedrahita, and N. Maeda. 1992. Spontaneous hypercholesterolemia and arterial lesions in mice lacking apolipoprotein E. Science (Wash. DC). 258:468-471.

46. Plump, A. S., J. D. Smith, T. Hayek, K. Aalto-Setälä, A. Walsh, J. G. Verstuyft, E. M. Rubin, and J. L. Breslow. 1992. Severe hypercholesterolemia and atherosclerosis in apolipoprotein $\mathrm{E}$ deficient mice created by homologous recombination in ES cells. Cell. 71:343-353.

47. Schaefer, E. J., R. E. Gregg, G. Ghiselli, T. M. Forte, J. M. Ordovas, L. A. Zech, and H. B. Brewer, Jr. 1986. Familial apolipoprotein E deficiency. J. Clin. Invest. 78:1206-1219.

48. Kovanen, P. T., M. S. Brown, S. K. Basu, D. W. Bilheimer, and J. L. Goldstein. 1981. Saturation and suppression of hepatic lipoprotein receptors: a mechanism for the hypercholesterolemia of cholesterol-fed rabbits. Proc. Natl. Acad. Sci. USA. 78:1396-1400.

49. Spady, D. K., and J. M. Dietschy. 1988. Interaction of dietary cholesterol and triglycerides in the regulation of hepatic low density lipoprotein transport in the hamster. J. Clin. Invest. 81:300-309.

50. Ginsberg, H. S., L. L. Moldawer, P. B. Sehgal, M. Redington, P. L. Kilian, R. M. Chanock, and G. A. Prince. 1991. A mouse model for investigating the molecular pathogenesis of adenovirus pneumonia. Proc. Natl. Acad. Sci. USA 88:1651-1655.

51. Kowal, R. C., J. Herz, J. L. Goldstein, V. Esser, and M. S. Brown. 1989. Low density lipoprotein receptor-related protein mediates uptake of cholestery esters derived from apoprotein E-enriched lipoproteins. Proc. Natl. Acad. Sci. USA. 86:5810-5814.

52. Holmquist, L., K. Carlson, and L. A. Carlson. 1978. Comparison between the use of isopropanol and tetramethylurea for the solubilisation and quantitation of human serum very low density apolipoproteins. Anal. Biochem. 88:457460. 